\title{
JERONIMO GRIMALDI, UN EJEMPLO DE SUPERVIVENCIA POLITICA
}

\author{
Paulino García Diego
}

Ministerio de Defensa

RESUMEN: El embajador y secretario de Estado de origen genovés Jerónimo Grimaldi y Pallavicini, acometió iniciativas significativas en materia de relaciones internacionales. Pero tuvo asimismo una participación activa, pero silenciosa, en las intrigas y pugnas por el poder con Esquilache y, sobre todo, con Aranda, lo que le permitiría mantener su posición política durante casi trece años, entre 1763 y 1776.

Palabras clave: Jerónimo Grimaldi y Pallavicini, España, siglo XVIII.

\section{JERÓNIMO GRIMALDI, AN EXAMPLE OF POLITICAL SURVIVAL}

ABSTRACT: The ambassador and secretary of State Jerónimo Grimaldi y Pallavicini, of Genoese origin, undertook significant initiatives related with the foreign affairs. But he had also an active but discrete role on the intrigues and power struggles with Squillace and, above all, with Aranda, allowing him to maintain his political position for almost thirteen years, from 1763 to 1776.

Keywords: Jerónimo Grimaldi y Pallavicini, Spain, $18^{\text {th }}$ century.

El genovés Pablo Jerónimo Grimaldi y Pallavicini (1710-1789), embajador de España durante los reinados de Felipe V, Fernando VI y Carlos III y titular de la primera secretaria de Estado y Despacho entre 1763 y 1776, es una de las figuras significativas del siglo XVIII relativamente olvidada por la investigación histórica. Su prolongada actividad diplomática (1739-1763 y 1777-1784) no fue sustancialmente diferente de la de buena parte de los embajadores del periodo, a excepción de su activa participación en las negociaciones del tercer Pacto de Familia. 
Pero a esta etapa debe sumarse su ejercicio del cargo de primer secretario de Estado y del Despacho de Carlos III durante más de trece años (1763-1776), lo que le convierte en el titular, después de Floridablanca, que más tiempo se mantuvo al frente de esa secretaría a lo largo del siglo XVIII.

En justicia debe atribuirse a Jerónimo Grimaldi la responsabilidad de llevar a cabo las decisiones reales en materia de política exterior en asuntos como la gestión -iniciada por Ricardo Wall- de las consecuencias de la Guerra de los Siete Años, entre ellas la ocupación efectiva de la Luisiana; afrontar unas complicadas relaciones con Gran Bretaña que a punto estuvieron de provocar un conflicto por el contencioso de las Malvinas; acometer, particularmente tras la caída de Choiseul, un pragmático y discreto alejamiento de Francia, cada vez menos sensible a las pretensiones españolas; y mantener la concurrencia de esfuerzos de España, Nápoles y Parma en los asuntos de Italia, particularmente en lo tocante a las relaciones con el Papado. Durante la secretaría de Grimaldi se prestó también particular atención a los Reales Sitios y al impulso del servicio postal, creando los correos marítimos con América, competencias ambas ajenas a la política exterior, pero asignadas a su departamento.

A estas actuaciones hay que sumar otras de análoga importancia que Jerónimo Grimaldi no llegaría a ver culminadas, pero en las que tuvo un papel relevante. Entre ellas destacan la solución definitiva al litigio sobre la Banda Norte del Uruguay, la ocupación de la colonia de Sacramento y la paz con Portugal; los primeros apoyos, con la precaución obligada, a los insurrectos de las colonias inglesas de Norteamérica en el marco de una política de alianzas que conduciría a obtener el desquite de la derrota de 1763 y a la recuperación de la mayor parte de los territorios perdidos a manos de Gran Bretaña; y por último, sentar las bases para asegurar la libertad de navegación en el Mediterráneo por medio de la normalización de las relaciones con Marruecos y de la adopción de medidas diplomáticas y militares frente a las regencias del Norte de África. Sería a Floridablanca a quien correspondería recoger los frutos de estas acciones, pero es obligado señalar que los principales éxitos de don José Moñino en sus más de tres lustros al frente de la secretaría de Estado se basaron en mayor o menor medida en las gestiones de su predecesor.

Sin embargo, la aproximación a su figura que pretende este artículo no se referirá al desempeño de Grimaldi en las competencias ordinarias de la secretaría de Estado, sino a su papel en la política interna y en las pugnas por el poder durante el periodo 1763-1776, tarea esta ultima en la que se mostró como un hábil superviviente político y un diestro urdidor de intrigas. Estos aspectos son poco conocidos y sobre ellos existen únicamente escasos testimonios escritos significativos, en buena parte porque "el lindo abate" con casi total seguridad se ocupó minuciosamente de hacer desaparecer las pruebas de su participación en asuntos controvertidos. De hecho, ya durante su etapa diplomática pondría en práctica sus dotes saliendo indemne de la conspiración contra Ensenada, del que 
podía considerarse una de sus "criaturas", al tiempo que ganaba el favor de Wall, principal artífice de la caída de don Zenón.

\section{Grimaldi, secretario de Estado}

Remontándose al principio del periodo que nos ocupa, la noticia de la dimisión de Ricardo Wall, presentada el 16 de agosto de 1763, obligaba a buscar apresuradamente un candidato para sustituirle, habida cuenta de que los intentos del monarca para disuadirle no habían tenido éxito. Después de varios días de incertidumbre, en los que se barajaron nombres como los de Llano o Ensenada, finalmente el 1 de septiembre Carlos III aceptaba la renuncia de Wall y en la misma fecha firmaba en San Ildefonso la designación de Jerónimo Grimaldi como primer secretario de Estado'.

Los motivos que Ilevaron a esta elección son diversos. El más determinante fue sin duda la buena consideración como diplomático que Carlos III tenía de Jerónimo Grimaldi, sin que esta opinión se contradijese con la idea del monarca de que había muy pocos candidatos idóneos para el puesto de secretario de Estado, como confiaría a Tanucci afirmando que había elegido a Grimaldi "por considerar que había falta de sujetos y que este era el mejor de todos" 2 . En cualquier caso, el juicio real sobre las aptitudes como diplomático del genovés se había puesto de manifiesto al haberle otorgado dos años antes su confianza para la negociación de los pormenores de la alianza con Francia, lo que Grimaldi había llevado a cabo de forma diligente independientemente del resultado de la guerra.

En la decisión de Carlos III sin duda influyó el juicio sobre Grimaldi de Ricardo Wall, que podía considerarse en cierta manera su patrocinador y que afirmaría poco después de su relevo que "La prudencia del Rey ha sabido reemplazarme con muchas ventajas..." ${ }^{3}$. De la opinión de Wall sobre Grimaldi dejaba constancia el testimonio del embajador austriaco, Rosenberg: "No menos plenamente satisfecho está D. Ricardo Wall (...) mientras Grimaldi, a través de las memorias remitidas hasta la fecha ha adquirido ya tal crédito como para ser consultado en los asuntos más relevantes"14. Grimaldi era también el candidato idóneo para Choiseul desde el punto de vista de la continuidad de la alianza con España, por

1. Carta de Wall a Tanucci de 1 de septiembre de 1763, AHN, Estado, Legajo 3421,2. Vid. Escudero J. A., Los orígenes del Consejo de Ministros. La Junta Suprema de Estado, Madrid, 1979, pp. 289-303.

2. Ibídem, p. 297.

3. Téllez Alarcia, D. "Guerra y regalismo a comienzos del reinado de Carlos III: El final del ministerio Wall", Hispania, no 209, 2001, p. 1090.

4. En Berichte der diplomatischen Vertreer des Wierner Hofes aus Spanien in der Regierungzeit Karls III, 1970, t. II, informe de 16 de enero de 1762, p. 14. Cit. Juretschke, H., "El marqués de Grimaldi visto por los representantes diplomáticos de Viena acreditados en la Corte de Carlos III", en Cuadernos de la Escuela Diplomática, num. 3, 1989, p. 72. 
lo que su nombramiento podía interpretase en alguna medida como una nueva sanción por parte de Carlos III del tercer Pacto de Familia.

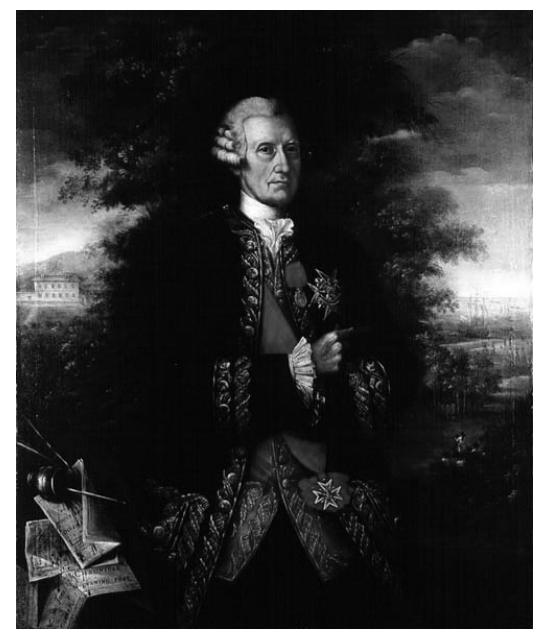

Figura 1. Retrato de D. Ricardo Wall. Fuente: http://upload.wikimedia.org/wikipedia/ commons/2/26/Ricardo_Wall.jpg.

El 22 de septiembre de 1763 recibía Jerónimo Grimaldi la comunicación de su nombramiento, sin duda inesperada para él porque al margen de su carácter ambicioso era ante todo un hombre realista, y un ascenso tan fulgurante no estaba incluido en sus previsiones. Dos días más tarde, después de despedirse de Choiseul y de Luis XV, partía definitivamente hacia España. Para reemplazarle se había designado al conde de Fuentes como embajador extraordinario el 2 de septiembre.

Con cierto retraso, puesto que se le partió la silla de posta durante el viaje, llegaba Grimaldi al Escorial el 9 de octubre de 1763 a mediodía. Allí fue recibido por el rey y por Wall, que esa misma mañana había efectuado el relevo de la secretaría de Guerra con Esquilache y que se ofreció a continuar despachando con el monarca algunos días más para dar tiempo a su sucesor a recuperarse de las fatigas del viaje ${ }^{5}$. Finalmente, en la mañana del día 14 de octubre de 1763 Wall entregaba a Grimaldi "el despacho de los negocios" de la secretaría de Estado 6 . Unos días antes, el 10 de octubre, Carlos III había firmado la orden de que se aumentasen en 180 escudos las retribuciones asignadas inicialmente al nuevo secretario (120 escudos de sueldo y otros 180 de masa).

Cuando Jerónimo Grimaldi llegaba a Madrid la situación en los círculos próximos a la corte tenía bastantes semejanzas con la existente en el periodo final del reinado de Felipe V. En concreto una buena parte de la aristocracia tradicional,

5. Rodríguez Casado, V., La política y los políticos en el reinado de Carlos III, Madrid, 1962, pp. 88-91.

6. Téllez Alarcia, D., "Guerra y regalismo..., p. 1072. 
que se veía a sí misma como "españolista" y que se aglutinaría en torno al duque de Alba y alrededor de Aranda y su "partido aragonés", mantenía la misma actitud que había sostenido el partido aristocrático en tiempos del primer Borbón. Este grupo acogió con disgusto la decisión de Carlos III al Ilegar a España de situar a varios de sus antiguos colaboradores en la administración, lo que suponía dejar de lado la "nacionalización" de la política iniciada durante el reinado anterior. La aristocracia contemplaba con progresiva desconfianza el aumento de la presencia de extranjeros en los puestos claves del gobierno, sobre todo por considerar que se hacía a costa de su "natural" participación en el poder. En este sentido el nombramiento de Grimaldi no hacía sino confirmar sus temores, puesto que conllevaba que las principales secretarías continuasen en manos foráneas (Grimaldi en Estado y Esquilache en Guerra y Hacienda). Pueden ser ilustrativas a este respecto la frase de Tanucci de que "Los españoles no quieren ni sufren ni héroes ni forasteros", y la siguiente afirmación del embajador inglés Rochford en su última carta a lord Halifax, apuntando la situación que esperaba al nuevo ministro:

La última cosa que hizo antes de retirarse el general Wall, fue el dejar a sus amigos a Grimaldi, que son los únicos que este tiene aquí. Los principales son, Fuentes que ha estado empleado en Londres, el príncipe de Masserano y el conde de Aranda, a quien se creyó durante algún tiempo destinado para ocupar el lugar de Grimaldi; pero que en el día trata de entrar en el ministerio de la Guerra, contribuyendo a la caída de Squilace. A estos hay que añadir don Agustín de Llano, oficial mayor de la secretaría de Estado, el cual, aunque en tiempos de Wall desempeñaba este mismo destino, ha sido uno de los partidarios más declarados de los franceses?

Como Wall, Grimaldi sería objeto apenas Ilegado a España de la atribución interesada desde ciertos círculos de filias y fobias por su nacionalidad, así como de constantes dudas sobre su patriotismo. Dada su doble condición de extranjero y de perteneciente a la baja nobleza, era natural además que pasase a ser incluido en la lista de "golillas", de la que sería considerado un miembro principal por la preeminencia de su posición. Se situaba por tanto Grimaldi en el punto de mira de la alta aristocracia autóctona aleccionada por el duque de Alba y radicalmente opuesta a que se continuase seleccionando para los niveles superiores de la administración a miembros de la baja nobleza y de la de nuevo cuño creada durante el reinado de Carlos III, dispuestos además a implantar las reformas ilustradas y enemigos de los privilegios tradicionales. Consecuentemente sería entre los "golillas" donde Grimaldi escogería a sus colaboradores y hombres de confianza.

Al hacerse cargo de la secretaría de Estado Jerónimo Grimaldi había cumplido ya cincuenta y tres años y contaba por tanto con una amplia experiencia vital y profesional. Plenamente consciente de que su fortuna se decidiría en las estancias reales,

7. Téllez Alarcia, D., "Guerra y regalismo..., p. 1074. 
sus cualidades personales le harían pronto agradable a los ojos de Carlos III, al que se esforzaría permanente por agradar y al que guardaría una acendrada lealtad.

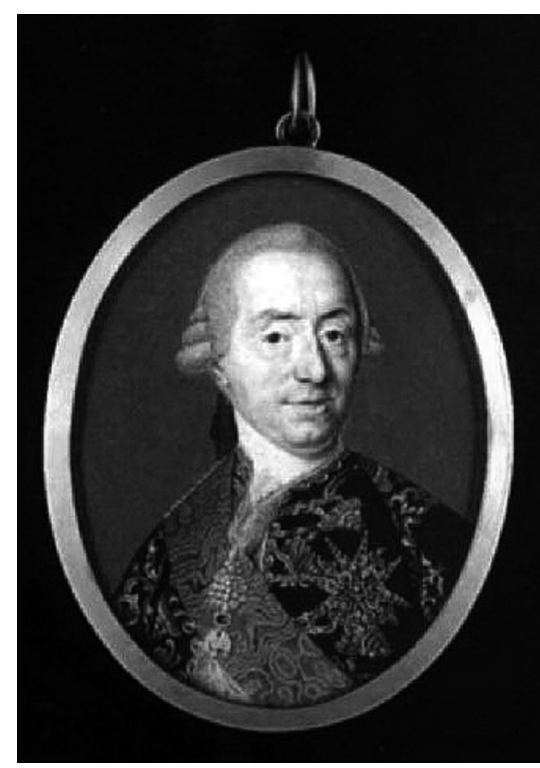

Figura 2. Retrato del Marqués de Grimaldi. Fuente: http://commons.wikimedia.org/wiki/ File:Jer\%C3\%B3nimo_Grimaldi.jpg.

La cordial relación que se establecería entre ambos, monarca y ministro, le serviría para sortear los intentos de los albistas de desgastarle, particularmente en la crisis de 1766. En cierta manera, el hecho de desarrollar su actividad en un relativo segundo plano respecto a su competidor principal por el favor real, Esquilache, le convertiría en un blanco marginal de las críticas en estos primeros años, puesto que el poderoso secretario de Hacienda, y Guerra era el principal objetivo a batir para la aristocracia tradicional.

Hacía ya tiempo que Grimaldi había arrinconado su servicio a la Iglesia, vocación por otra parte nunca muy arraigada. De hecho, ya desde sus primeros años al servicio de Génova empleaba de cara al exterior su título de marqués y rehuía cualquier referencia a su condición de religioso. No por ello dejaba de observar las formalidades exigidas a un hombre devoto, aunque en su vida privada pondría de manifiesto una cierta liberalidad de costumbres.

Jerónimo Grimaldi era también un hombre refinado, interesado por las artes y las letras y con inquietudes ilustradas, que no tardaría en poner en práctica haciéndose ver en los teatros y promoviendo a su nivel las actividades culturales y científicas en la capital. Estas facetas, a diferencia de lo que sucedía con Esquilache, pesarían en su favor en una corte en lo que no cabía esperar que fuese demasiado bien recibido y le permitirían desenvolverse con soltura en los salones madrileños, en los que llegaría a adquirir cierta popularidad. 
Pero la relativa superficialidad que mostraba al exterior no se hacía extensiva a lo más profundo de su personalidad. Grimaldi fue en todo momento un agudo observador cuyas actuaciones estaban perfectamente medidas. El ministro amable y locuaz ocultaba tras su levedad un hombre ambicioso y calculador, capaz de urdir complejas tramas en torno a los asuntos que le concernían, al tiempo que puertas afuera manifestaba hacia ellos escasa afectación e incluso desinterés. De esto modo consiguió llevar a la práctica muchos de sus proyectos personales, desde la neutralización de sus principales competidores hasta la designación de su sustituto. Sin embargo, Grimaldi no llegaría a culminar aquellos otros asuntos que requerían un carácter enérgico y resolutivo del que carecía.

\section{Los secretarios italianos}

La situación en la que se veía Grimaldi al llegar a Madrid en relación con los notables españoles auguraba ciertas dificultades, pero tampoco parecía sencilla la relación que cabía esperar de su convivencia con el otro secretario italiano, Leopoldo di Gregorio, el marqués de Esquilache, cuyas competencias habían aumentado tras la dimisión de Wall al añadir a los asuntos de hacienda la cartera de Guerra y que llevaba en el gobierno cuatro años, desde la Ilegada a España de Carlos III, por lo que había consolidado plenamente su posición ${ }^{8}$.

Aunque de puertas afuera la entrada de Grimaldi suponía el refuerzo de la influencia italiana en el gabinete, desde el primer momento surgieron roces entre ambos secretarios a causa de su afán por ganarse el favor real. En esta pugna Grimaldi contaba con cierta ventaja porque suscitaba mayor simpatía al monarca que Esquilache.

Una ocasión que pondría a prueba la competencia entre ambos sería la constitución de la junta de secretarios, precursora del gabinete ministerial. Se trataba de una iniciativa de Grimaldi, que pretendía estar al tanto de lo que sucedía en el resto de secretarías. En noviembre de 1763 conseguía que se despachase una orden real para que los secretarios se reuniesen semanalmente en junta, una especie de comisión para la defensa del imperio formada por Esquilache, Arriaga y el mismo, que sería el encargado de dar conocimiento de la disposición real a los otros dos secretarios ${ }^{9}$ :

Considera el rey N.S. con la superioridad de sus luces que será muy útil a su real servicio que entre V.E., el Sr. D. Julián de Arriaga y yo haya absoluta reciproca inteligencia de los negocios que manejamos baxo de

8. Vuelto a Italia con toda su familia como resultado de los disturbios acontecidos en 1766, terminaría desempeñando el puesto de embajador de España en Venecia hasta su muerte en 1785. Fernández, R., Carlos III, Madrid, 2001, p. 258.

9. Comunicación de Grimaldi a Esquilache de 9 de noviembre de 1763, AGS, Hacienda, legajo 7. 
su soberano gobierno; y ha resuelto que nos juntemos un día por semana, para que alternativamente nos confiemos el estado de los negocios que cada cual tiene a su cargo, sin reserva de sus antecedentes, de su presente estado, de miras que se esperan, efectos logrados o que se esperan lograr, para que examinándolos y discutiéndolos, expongamos a S.M. los medios de mejorar su dirección en cada ramo. Particípolo a V.E. de orden de S.M. para su inteligencia y cumplimiento; y en los mismos términos lo aviso a D. Julián de Arriaga.

En las reuniones, que se fijaron los lunes, se discutía básicamente la política colonial y comercial puesto que en ellas se analizaban las relaciones exteriores así como las cuestiones relativas a Ejército y Marina, a las Indias y a la disponibilidad de recursos económicos para sostener las decisiones adoptadas. Carlos III autorizó su formación contra la voluntad de los otros dos implicados, pero Esquilache no tardó en comprender las posibilidades de ese organismo y junto con Grimaldi se hizo con el control de la comisión, ya que Arriaga, hombre tranquilo y honesto, pero escasamente valorado por sus colegas y por los embajadores extranjeros con los que tenía que tratar, se vio gradualmente marginado. Por su parte Grimaldi intentaría sin éxito implicar más activamente a Arriaga a fin de desplazar a Esquilache, pero sería este quien finalmente conseguiría liderar la junta ${ }^{10}$. En cuanto a Muñiz, en ningún momento se contó con su opinión ni se contempló su participación en estas reuniones, lo que dejó fuera de la comisión las cuestiones de gobierno interior y Justicia, que de haber sido incluidas la habrían convertido en la práctica en un consejo de ministros según el concepto actual del término.

A estas reuniones es dudoso que asistiese Carlos III, quien probablemente se limitaba a escuchar las conclusiones que le transmitirían Grimaldi o Esquilache. Según Ferrer del Río, en el curso de las mismas Arriaga quería pocas novedades, Esquilache, seguro de la aprobación del rey para plantear las que tenía meditadas "dejaba decir al anciano marino y las perfeccionaba en secreto" y Grimaldi "se manifestaba muy entendido en las practicas del comercio". El mismo Ferrer del Rio afirma sin embargo que Halifax, el recientemente nombrado embajador británico, no era de esa opinión y decía que "Grimaldi no deja de tener cierto mérito, pero ignora cuánto dice en relación con el comercio, o más bien desconoce los intereses de España en este punto..."11.

La rivalidad entre los dos secretarios italianos dio píe a la intervención del embajador francés en favor de Grimaldi, no solo por ser partidario declarado de Francia sino también para contrarrestar a Esquilache, sospechoso de favorecer a Gran Bretaña. Testimonios de la época, como el del embajador Ro-

10. Sobre la figura de Arriaga resulta de particular interés la tesis de Baudot Monroy, M., Julián de Arriaga y Rivera. Una vida al servicio de la Marina (1700-1776), UNED, 2010.

11. En Ferrer del Rio, A., Historia del reinado de Carlos III en España, I, Madrid, 1856 (reed. 1988) p. 452. 
senberg en su correspondencia con Kaunitz, dan fe del creciente ascendiente de Grimaldi sobre el rey. El representante austriaco afirmaría en su carta de 24 de enero de 1764, al tiempo que informaba del traslado de las reuniones de los secretarios a los jueves, lo siguiente: "parece que el rey comienza a tener bastante confianza en él (Grimaldi), incluso para tratar cosas distintas de los asuntos extranjeros"12.

\section{Los motines de 1766}

Los motines de la Semana Santa de 1766 supusieron un punto de inflexión en la carrera de Grimaldi. En las revueltas, entre otros factores, había influido decisivamente el rechazo, convenientemente fomentado desde instancias superiores, de buena parte del pueblo de Madrid a los gobernantes extranjeros, al que contribuían la todavía reciente derrota frente a Inglaterra y la conducta no siempre prudente de algunos de ellos. A título de ejemplo, en un documento titulado "Ordenanzas que establece un nuevo Cuerpo para defensa del Rey y la Patria; las publica el amor español, para quitar la opresión con que intentan violar estos dominios", firmado el 12 de marzo de 1766, se daban consignas para pertenecer a una organización secreta que, entre otras consignas, tenía la de "restablecer el buen Gobierno" eliminando a Esquilache y a Grimaldi, el primero por ser considerado enemigo del pueblo y el segundo por excesivamente francófilo ${ }^{13}$.

La misma aspiración sostenía el conde de Aranda, alrededor del cual se reunirían, constituyendo el Ilamado "partido aragonés", aristócratas, eclesiásticos, consejeros y funcionarios no necesariamente opuestos a la reforma pero hostiles a los instrumentos elegidos por el rey, los "golillas", hacia quienes mostraban un desdén elitista. Aranda, que había sido designado Capitán General de Valencia y Murcia en febrero de 1764, estaba presuroso por abandonar la Junta militar que presidía, responsable de juzgar a los responsables de la perdida de La Habana en 1763, a causa de las intrigas que comenzaba a intuir a su alrededor. Estas habían sido en buena parte promovidas por Ensenada para salvar a su patrocinado Superunda, que había aconsejado la capitulación al gobernador Prado para salvar los caudales que traía desde Perú. Grimaldi, por su parte, pretendía retener a Aranda, que recibió orden de no incorporarse a su nuevo destino hasta haber concluido sus funciones al frente de la Junta militar.

Como es sabido, el domingo de Ramos estallaba la primera revuelta popular en la Plaza Mayor, reuniéndose unas dos mil personas que se dirigieron primero a la mansión de Esquilache, donde hirieron un servidor del marqués que intentó impedirles el paso, echaron algunos muebles por la ventana y saquearon la des-

12. Escudero López, J. A., Los orígenes..., p. 948.

13. Olaechea Albistur, R., Las relaciones hispano-romanas en la segunda mitad del siglo XVIII, Zaragoza, 1965, pp.318 y 355. 
pensa. Luego se dirigieron hacia la mansión de Sabatini, deteniéndose de paso en la casa de Grimaldi, que se limitaron a apedrear antes de seguir viaje. Esta "visita" se explica porque, si bien Esquilache fue el principal objetivo de los amotinados, también se habían difundido acidas criticas sobe otros extranjeros, en concreto sobre Grimaldi, del que en una relación satírica de esos días se decía ${ }^{14}$

Si en Madrid han pedido a un Squilace, en Milán han colgado a su mismo padre:

también Grimaldi fue traidor a su patria, bueno va el baile

Tras los primeros enfrentamientos con la Guardia Valona, con muertos por ambas partes, Carlos III, alarmado, optó por aceptar las peticiones de los amotinados a regañadientes. A continuación, bien por no creer que la situación estuviera controlada bien porque pensaba en algún tipo de castigo para los revoltosos, tomo la decisión de marchar a Aranjuez.

Acabado Esquilache, que partiría de Cartagena el 5 de abril de 1766, Grimaldi se veía en la obligación de dirigir el timón de la nave gubernamental en aquellas difíciles circunstancias, haciéndose cargo interinamente de la cartera de Guerra. En Madrid, las aguas habían vuelto a su cauce, pero el rey y sus ministros continuaron en Aranjuez, donde permanecerían durante los ocho meses que siguieron al motín.

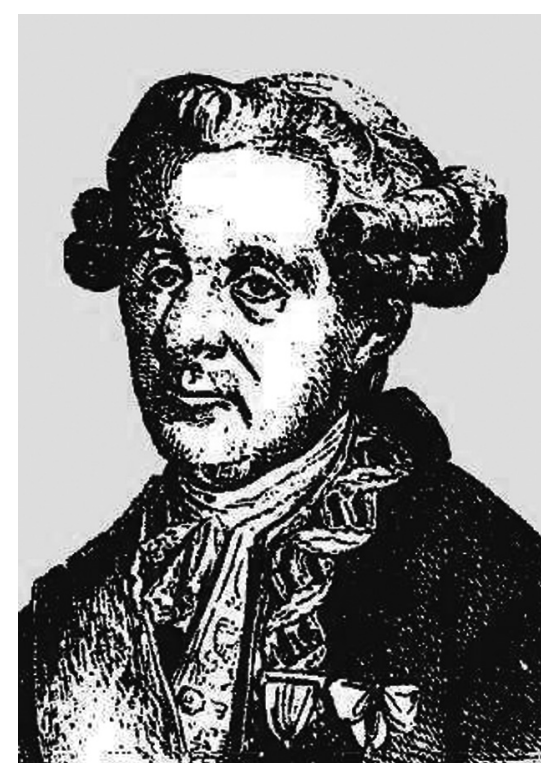

Figura 3. El Marqués de Esquilache. Fuente: https://upload.wikimedia.org/wikipedia/ commons/c/c4/Esquilache-2.jpg.

14. En Egido López, T., "La oposición y el poder: el desastre de Argel (1775) y la sátira política", Actas del congreso internacional sobre "Carlos III y la llustración", Vol. 1, 1989, el Rey y la Monarquía, p. 424. 
Grimaldi notificó a los embajadores españoles en el extranjero que el motín había sido obra de algunos instigadores, tratando de evitar dar la impresión de que los tumultos habían tenido especial gravedad y de que no habían sido "demasiado funestas las resultas". Así, a finales de marzo daba instrucciones a Azpuru, embajador en Roma, en el sentido de que "Acaso no faltará quien lo pinte muy diverso del que ha sido, por lo que es necesario procure VS. que en las noticias públicas de esa capital se ponga tal cual yo le refiero". En la misma línea, el 2 de mayo remitía a Choiseul una apresurada versión oficial de lo acaecido en los motines ${ }^{15}$.

El 27 de marzo Grimaldi ordenaba a las tropas establecidas en las cercanías de Madrid que se concentrasen en torno a Aranjuez. Este dato confirma la sensación de que el rey y sus ministros seguían temerosos, en espera de nuevas violencias populares. El 28 el propio Grimaldi, sintiéndose poco capaz de dominar la situación por sí mismo, llamaba al conde de Aranda para que partiese desde Valencia, donde había puesto coto de inmediato a la revuelta, y se dirigiese a Aranjuez con todas sus tropas. Al día siguiente daba instrucciones para que un regimiento de caballería se apostase estratégicamente en los pasos del Guadarrama, en la que sería una de sus últimas disposiciones como secretario de Guerra, puesto que el 3 de abril hacía entrega de esa cartera a Múzquiz.

Superadas las primeras jornadas de confusión y en vía de sofocarse las algarabías, se ofrecía a Jerónimo Grimaldi una ocasión propicia para consolidar una posición preeminente en el gobierno. No en vano había dedicado buena parte de sus esfuerzos desde su llegada a España a tratar de neutralizar a Esquilache y huido éste, dejaba tras de sí un vacio que Grimaldi se apresuró en intentar cubrir. Su propósito inicial era el de aprovechar la junta de secretarios, con la idea primero de gobernarla y después de reforzar su papel, convirtiéndola en una especie de consejo ejecutivo que se situaría por encima de las secretarías. Para ello veía necesario dar entrada a nuevos miembros, lo que en opinión de Choiseul era un craso error puesto que solo contribuiría a diluir el hasta entonces discreto liderazgo del gabinete por parte de Grimaldi.

De acuerdo con sus intenciones, Grimaldi propuso al rey que la junta de secretarios continuase reuniéndose en Aranjuez, en primer término para tratar de los motines de Madrid, lo que se haría efectivo a partir del 8 de abril de 1766. Los primeros integrantes de la junta fueron los cuatro secretarios: Arriaga, Muniaín, Múzquiz y el propio Grimaldi, el cual consiguió que Carlos III aprobase su ampliación a finales de abril para incorporar a Roda y a algunos grandes de España que eran consejeros de Estado y que se encontraban a Aranjuez: los duques de Alba y Sotomayor, Jaime Masones de Lima, Ricardo Wall y el conde de Fuentes, primo de Aranda. Grimaldi trataría a partir de ese momento de conformar a unos

15. Carta de Grimaldi a Azpuru de 26 de marzo de 1766, AEER, legajo 215, cit. R. Olaechea Albistur, R., "Contribución al estudio del motín contra Esquilache (1766)", Tiempos Modernos, 8, 2003, p. 41. 
y a otros, mostrándose bien avenido con todos y sintiéndose respaldado por la confianza del rey y por el apoyo de la reina madre, Isabel de Farnesio. Pero tal y como temía Choiseul, en poco tiempo se vería desplazado a un segundo plano al ponerse de acuerdo los notables españoles de una y otra tendencia presentes en la junta para evitar que otro extranjero, al que en el fondo detestaban, pasase a ocupar el lugar de Esquilache ${ }^{16}$.

El 9 de mayo de 1766 se reunía la junta para debatir la conveniencia de anular todas las concesiones hechas por el rey como condición para su regreso a la capital. A la vista de la aprobación de la propuesta Grimaldi, intuyendo en ello una oportunidad para Aranda que no estaba dispuesto a admitir, optó por endurecer aún más las condiciones añadiendo una nueva demanda, además del regreso de la guardia valona que el conde había solicitado. La condición en cuestión era que también pidiese la Plebe la nulidad de lo que el rey había concedido. Al respecto sugeriría Grimaldi:

Admirable es el pensamiento de pedir la introducción en Madrid de los valones. Sería una ofensa máxima al Soberano el limitarle sus guardias, y cabe que sea la mayor que hizo al Rey la desenfrenada Plebe de Madrid, pidiéndole que apartase aquellas guardias de la Capital. Pero no hallo que ésta sola circunstancia repare lo pasado en el modo posible, ni dé aquellas morales seguridades para lo venidero, que se deben buscar. Para probar del todo el arrepentimiento haría falta, pues,

$1^{\circ}$ Descubrir los motores, instigadores y capataces del motín.

$2^{\circ}$ Castigar severamente a los que han incurrido después del término del perdón en escritos y discursos sediciosos; caso que no sea posible ni se haya logrado aún venir en conocimiento de los autores de los escritos (...)

$3^{\circ}$ Que además de pedir la restitución a Madrid de las guardias valonas se pidiese por gracia la retractación de todos los artículos que solicitó la Plebe, del Rey; esto se entiende en los términos posibles; a saber los abastos al precio que correspondan; (...) la renovación de los bandos contra sombreros gachos y embozos, no tan solamente porque se trata de una legislación antigua, necesaria a la policía, y buen gobierno de todo Pueblo, pues no se hallará ninguno en Europa en que se permita una máscara perpetua, mas sí con más particularidad, para subsanar la misma afrenta hecha al Soberano...

Seguro de que una investigación sobre los promotores de la sublevación no iba a implicar efectos colaterales para sí mismo, Grimaldi proponía también acerca de las medidas de policía que debía tomar Aranda lo siguiente: 492.

16. En Gallego, J. A., El Motín de Esquilache, América y Europa, Madrid, 2003, pp. 429- 
En cuanto a la seguridad moral para lo venidero, limpiado Madrid de vagamundos, mujeres perdidas, pobres; formada una filiación exacta de todos sus habitadores, establecida una buena regla de Policía, para saber diariamente los que entran por las Puertas de la Ciudad, expeliendo de ella al tercer día todo individuo que no encuentre empleo, o no tenga negocio conocido; y sobre todo manteniendo espías y exploradores en las casas y parajes públicos y privados, para estar informados del modo de discurrir y pensar de las gentes, como se practica en todas las grandes ciudades del mundo bien gobernadas, y finalmente teniendo Madrid un Presidente de Castilla de tanta habilidad, celo, actividad, prudencia y firmeza, no parece que después de todas estas medidas, se pueda nunca recelar de ver renovado un ejemplar tan funesto.

Temiendo una nueva explosión popular en Madrid en ausencia del rey el Consejo de Castilla hizo pública una nota, recordando "la seguridad ofrecida por SM." y negando el rumor de que se había dado orden de que "viniese artillería o tropa extranjera". Lo cierto es que el monarca no se decidía a regresar a Madrid, donde su tardanza se interpretaba en sentido negativo. En este contexto solo la llegada de Aranda consiguió tranquilizar a Carlos III, pasando el conde a ser visto como el único capaz de restaurar la normalidad para desesperación de Grimaldi, cuyas urdimbres perdían fuerza por momentos. Aranda, ante todo un hombre de carácter, marcadamente resolutivo y sin excesivas concesiones a la corrección política, no tardaría en poner en práctica sus dotes imponiendo orden en el caos y hasta logrando implantar el uso de la capa corta y suprimir el uso del sombrero de ala ancha.

Grimaldi, sin capacidad de maniobra, se vería reducido a la condición de espectador, con el único consuelo de que en medio de la confusa situación provocada por los motines se desatase una soterrada lucha por el poder en el seno del grupo de colaboradores de Carlos III, divididos entre "albistas", como Aranda y los regalistas Roda, Campomanes y Moñino, y "ensenadistas", que contaban con cierto apoyo popular y con el de los sectores más politizados de la Compañía de Jesús. Desde el primer momento resultó evidente que los "albistas" tenían todas las de ganar. Uno de ellos -Roda- era ya ministro; Campomanes era el fiscal del Consejo de Castilla y Aranda, por su parte, parecía ser el único hombre capaz de controlar la situación. En definitiva, los motines favorecieron a los "albistas", que ya en las primeras reuniones de la junta de gobierno consiguieron desbaratar la posibilidad de un retorno de Ensenada. Carlos III tendría que echar mano de este grupo político, el más sólido en aquellos momentos en los que era imposible adivinar el alcance de la tormenta social, en un momento en el que en Aranjuez persistían hondos temores, como muestra el hecho de que todavía el 10 de abril Múzquiz pidiese 30.000 balas de fusil con destino a Aranjuez, que debían ser enviadas "con toda precaución y disimulo...".

Uno de los propósitos de las algaradas era el alejamiento de los extranjeros del gabinete, lo que se solo se conseguiría parcialmente. Después de su caída 
Esquilache sería enviado a un dorado ostracismo en la embajada de España en Roma, destino que se debería precisamente a la propuesta de Grimaldi, lo que hace suponer que las pugnas entre ambos ministros por obtener el favor del rey quedaron orilladas una vez que Esquilache desaparecía de escena. Esta circunstancia satisfacía tanto la ambición de Jerónimo Grimaldi como los intereses de Francia.

Sin embargo, la intentona de Grimaldi de afianzarse en solitario ante Carlos III se había visto frustrada. Aranda se situaba ahora por delante de él y debía conformarse con mantener su posición en la secretaría de Estado. No hay que olvidar que el mismo Grimaldi había sido objeto de acidas sátiras aireadas por todo Madrid y que, aunque lograba sobrevivir políticamente a la mayor crisis política del reinado de Carlos III, en algún momento se vio tan cuestionado como para llegar a plantearse, más o menos sinceramente, su retirada. De esta posibilidad alertaba durante la primera quincena de mayo Lebzeltern, ayudante de Rosenberg, a Kaunitz, añadiendo a las informaciones sobre la pretensión de abandono de la política de Grimaldi otras acerca de una especie de coalición para forzar su salida en la que participarían "el duque de Alba, el confesor real Osma, el ayuda de cámara Pini y algunos grandes de España"17.

A este respecto Ossun y Beliardi, temerosos de que el más afrancesadísimo de los ministros españoles, en palabras de Tanucci, saliese muy debilitado de esta prueba, no podían sino tratar de apuntalar a su colega y aliado, contribuyendo de paso a la salida definitiva de Esquilache, supuestamente favorable a Gran Bretaña. Tal era la afinidad entre el secretario de Estado y el embajador y cónsul franceses que a raíz del motín se llegaría a propagar el rumor infundado de que Grimaldi había sido su promotor, ayudado por Ossun y Beliardi, con el objeto de derribar a Esquilache. Entre los representantes diplomáticos extranjeros no se otorgó credibilidad a esta posibilidad, como ponía de manifiesto el embajador portugués Sá de Melo al informar a Pombal el 28 de marzo sobre los sucesos, aunque sí se dio por probable en algunas legaciones una posible implicación de Beliardi, sobre la que el representante sardo, Roubione, alertaba a Turín el 7 de $a_{b r i l^{18}}$. En cualquier caso, la no disimulada preferencia de Grimaldi por Francia y la mala acogida que aparentemente tenía esa actitud en Madrid estarían presentes en la correspondencia diplomática del periodo, como reflejaba el danés Larrey al señalar a su corte en agosto de 1766 que "Francia tenía demasiada necesidad de Grimaldi. Francia lo ha sostenido (en los sucesos del motín), y no dudo que, a la larga, será Francia quien lo haga triunfar de los obstáculos que encuentre, procedentes del despotismo de su departamento, principalmente del poco crédito que ha conseguido hasta el presente en el espíritu de su Señor el rey"19.

17. Berichte, III, p. 359, en Escudero López, J. A., Los orígenes..., p. 315.

18. Gallego, J. A., El Motín..., p. 349.

19. Carta de Larrey a Bernstoff de 21 de agosto de 1766, RTKUA, Spanien, B, 25. 
Pero en todo caso el factor determinante para la continuidad de Grimaldi, que permanecería al frente de la secretaría de Estado sin verse afectado sustancialmente por los motines, sería la expresa voluntad de protección del soberano, que no dudaría en acallar las voces que pretendían forzar su caída.

Tras la desaparición de Esquilache Carlos III se vio obligado a introducir una serie de cambios en el equipo gobernante, dando entrada para su relevo en las carteras que ocupaba a dos políticos poco conocidos y de talante reformista moderado: Miguel de Múzquiz en Hacienda y Juan Gregorio de Muniaín en Guerra. Asimismo, el monarca optó por sustituir al conservador obispo de Cartagena, Diego de Rojas, por el conde de Aranda, que presidiría el Consejo durante siete años. La elección de Aranda seguía los consejos de los sectores reformistas y se oponía a los de la aristocracia conservadora, encabezada por el duque de Alba. A pesar de la designación de Aranda la correlación de fuerzas en el ámbito reformista se inclinaba a favor de los "golillas", que impusieron su mayor presencia en la administración política y en el círculo del rey. En otro orden de cosas, el motín de Esquilache supondría la definitiva marginación política de Ensenada, al que el rey desterraría a Medina del Campo a pesar de haberle sacado de su anterior confinamiento, con el argumento de que durante la revuelta los amotinados, inducidos por algunos aristócratas, habían reclamado que don Zenón ocupase algún puesto político destacado.

En parte secuela de los motines, el siguiente asunto de gran calado que centraría la atención del gobierno sería la expulsión de los jesuitas (con 2.800 miembros en España y 2.400 en América ${ }^{20}$.En 1767 se procedía a la misma, siguiendo la senda marcada por Portugal en 1759 y por Francia en 176421. La ocasión surgiría con motivo de la supuesta participación de los jesuitas en los motines del año anterior, que tanto habían conmovido el ánimo de Carlos III. Para fundamentar la decisión real Campomanes redactaría una Pesquisa Secreta en la que los jesuitas serían acusados de formar "una liga y unión ilícita contra el Estado dentro del reino, lo cual podría trastocar el trono de aquí a un tiempo". Tras la consulta de dos comisiones formadas en el Consejo de Castilla, la acción fue fulminante y en dos días se puso a los jesuitas en las fronteras del reino, operación en la que Aranda se mostró ciertamente eficaz ${ }^{22}$.

Jerónimo Grimaldi fue uno de los miembros de la junta que votó a favor de la expulsión de los jesuitas. Si esto causó alguna extrañeza fue porque su posición regalista no era públicamente conocida cuando accedió al puesto de secretario de Estado, ya que más bien se le tenía por lo contrario. Precisamente este rumor

20. Para los aspectos generales de la expulsión Vid. Giménez López, E. (coord.), Expulsión y exilio de los jesuitas españoles, Alicante, 1997.

21. Vid. Mestre Sanchís, A., "Reacciones en España ante la expulsión de los jesuitas de Francia, en E. Giménez López (coord.), Expulsión..., pp. 15-40.

22. Vid. Egido, T., Las causas gravísimas y secretas de la expulsión de los jesuitas por Carlos III, Madrid, 1994. 
había sido la causa de que en los primeros momentos de su ministerio Grimaldi fuese objeto de las críticas de Tanucci ${ }^{23}$. Las tesis y la vehemencia del ministro napolitano en relación con el asunto terminarían influyendo en el antijesuitismo del secretario de Estado, más coyuntural que por convicción, tal y como pondría de manifiesto Colloredo en su informe a Kaunitz del 29 de agosto de 1768, en el que afirmaba lo siguiente sobre Grimaldi ${ }^{24}$ :

manifiesta en todos los negocios religiosos siempre la opinión más moderada. Este ministro es tanto menos un enemigo personal de los jesuitas (...), cuanto que se le considera aquí en general como apoyo suyo y se le tiene por esta causa por sospechoso. A menudo me ha hablado de ello confidencialmente, demostrando de qué manera procuró esquivar siempre los enredos religiosos para tranquilizar su conciencia. $Y$ algunas veces añadió que mediante una modificación de parte de sus constituciones pudiera transformarse la Orden jesuítica en otra.

Se dio la paradoja de que Jerónimo Grimaldi fue el encargado de dar largas al nuncio Pallavicini, primo suyo, sobre la noticia de la expulsión, como relata Fernán Núñez ${ }^{25}$ :

El nuncio Pallavicini, primo del marqués de Grimaldi, ministro de Estado, había tenido alguna sospecha de que querían hacer tomar alguna providencia con los Jesuitas y preguntó sobre esto al primo, olvidado de que le respondería como ministro. Efectivamente, este le tranquilizó enteramente, y él escribió en consecuencia a su Corte; pero a la mañana siguiente justamente supo la expulsión, y de resultas del pesar, estuvo a las puertas de la muerte.

\section{La rivalidad con Aranda}

Ya se ha mencionado al hacer referencia a los motines que Grimaldi no veía con buenos ojos el encumbramiento de Aranda, previendo que su enfrentamiento con Esquilache para obtener el favor real sería sucedido por otro, sin duda más agrio, con el conde a los mismos efectos. Las relaciones entre ambos, inicialmente cordiales al menos en la forma, solo presentaban malos augurios dadas su discrepancia de pareceres y sus profundas diferencias en carácter y actitud, que se agravarían notablemente con ocasión de la controversia con Gran Bretaña por la soberanía de las islas Malvinas. Prácticamente desde sus primeros momentos se exteriorizaron las desavenencias entre ambos, circunstancia agravada por el

23. Carta de Tanucci al duque de Losada, AGS, Estado, Legajo 5982.

24. En Berichte ..., p. 74. Como fundamento de estas sospechas también se añadía el hecho de que Grimaldi había sido discípulo de la compañía.

25. Conde de Fernán Núñez, Vida de Carlos III, edición facsímil, Madrid, 1989, t. I, p. 212. 
rechazo hacia los extranjeros que Aranda compartía con la mayor parte de la nobleza española y por las maneras sibilinas de Grimaldi, el cual intentaba a toda costa evitar una confrontación abierta, en el fondo un reflejo de la que se daba entre el "partido aragonés" y los "golillas".

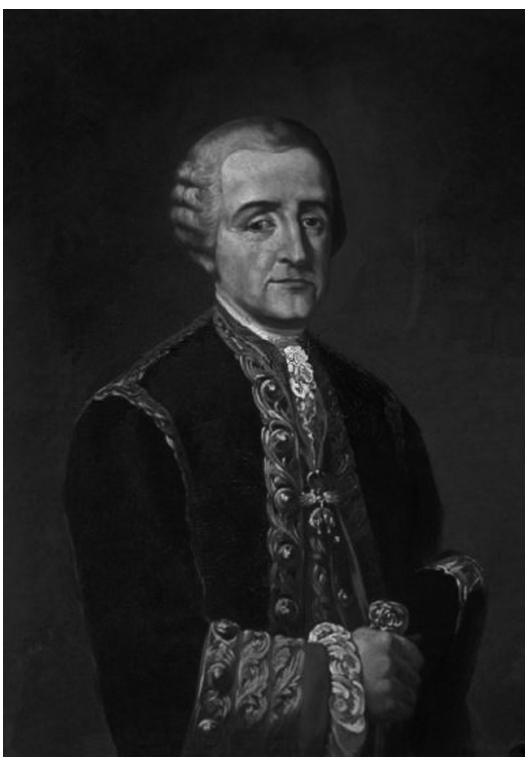

Figura 4. Retrato del Conde de Aranda. Fuente: http://upload.wikimedia.org/wikipedia/ commons/0/03/Pedro_Pablo_Abarca_de_ Bolea\%2C_Count_of_Aranda.jpg.

En esta pugna, soterrada al principio, Grimaldi buscaría ganar la buena voluntad del rey, para lo que tenía a su favor dos bazas importantes. Por una parte su personalidad: "hombre de voluntad flexible, suave en las palabras y deferente por naturaleza, que sabía agradar al Soberano", en palabras de Fernán Núñez, y por otra la reticencia de Carlos III a reemplazar a sus más cercanos colaboradores. Aranda, retomando de nuevo a Fernán Núñez, era por el contrario, "impetuoso, de carácter independiente, propenso en demasía a pagarse del parecer propio, y creyéndose necesario, hasta en presencia del Monarca tiraba de la cuerda más de lo justo"26.

Como se ha mencionado, la crisis de las Malvinas constituyó un punto de inflexión en la relación entre el contemporizador Grimaldi y el exaltado Aranda, provocando finalmente una brecha insalvable entre ambos. Los reproches del conde al secretario de Estado serían cada vez más frecuentes, llegando incluso a mostrarlos en presencia del rey. En otro orden de cosas, la posición de Grimaldi

26. A este respecto es ilustrativa la anécdota según la cual a la exclamación de Carlos III "Aranda, eres más testarudo que una mula aragonesa" contestó el conde "Perdone V.M., pues hay quien me gane a testarudo". Al preguntarle el monarca "¿Quién?" respondió Aranda "la sacra majestad del Sr. Carlos III, rey de España e Indias". Cit. Ferrer del Rio, A., Historia del reinado de Carlos III en España, Madrid, 1856 (reimp. 1988), libro IV, p. 105. 
favorable a Francia sería un factor que sus adversarios, entre ellos Aranda, aprovecharían para desgastarle, creando un estado de opinión que no pasaba inadvertido a los representantes extranjeros en Madrid, como se deduce de la correspondencia con sus cortes. A este respecto puede servir de ejemplo la afirmación del embajador austriaco Colloredo a Kaunitz sobre Grimaldi diciendo que en política exterior era "todo el francés", que Carlos III todavía no lo apreciaba mucho y que "la nación española, que lo tenía por extranjero, no lo apreciaba y menos aún lo quería, esto último quizá por su excesiva inclinación hacia Francia"27.

A principios de 1772 daba la impresión de que Aranda y los "aragoneses" habían alcanzado una posición de ventaja sobre los "golillas". Muestra de ello era el hecho de que tras el fallecimiento el 14 de enero de 1772 de Muniaín se designase para sustituirle en la cartera de Guerra a Ricla, partidario de Aranda y sucesor de Mina en la capitanía general de Cataluña. La realidad era sin embargo distinta, puesto que en los frecuentes enfrentamientos con Grimaldi este solía llevar la mejor parte cuando se trataba de conseguir el favor del rey. A ello se sumaría el desgaste a que Aranda se veía sometido por el enfrentamiento con los partidarios del duque de Alba. Todo ello terminaría desmotivándole y llevándole, tras conocer la petición de Fuentes de volver a España, a solicitar sustituir a éste como embajador en Francia, hacia donde partiría en agosto de 1773.

En la decisión de Carlos III de acceder a la petición de Aranda influirían tanto el aprecio que sentía por él, a pesar del poco tacto que el conde empleaba en ocasiones en su trato con el monarca, como el hecho de que no hubiese motivo alguno para retenerle, puesto que desde los motines de 1766 el país estaba en calma y no parecían ser necesarios a corto plazo los servicios de una personalidad tan resolutiva como incómoda. En un último gesto hacia su leal colaborador, el rey decidió honrarle manteniéndole al frente del Consejo de Castilla y de la capitanía general de Castilla la Nueva hasta su audiencia de despedida.

Jerónimo Grimaldi sin duda veía con agrado la separación de Aranda de la corte, a la que había contribuido, lo que era de general conocimiento hasta el punto de que por esas mismas fechas el embajador danés Saint Saphorin informaba a su corte de que "es ya publico que el marqués de Grimaldi ha sido el primer móvil del alejamiento del conde de Aranda"28. Pero tampoco quería colocar a su rival en la más importante de las embajadas españolas, sino que pretendía encontrarle un destino más anodino. Quizá movía a Grimaldi el recuerdo de que había sido precisamente la embajada en Francia la que en su momento le había impulsado decisivamente hacia la secretaría de Estado ${ }^{29}$.

27. Carta de Colloredo a Kaunitz de 7 de junio de 1768, Berichte, IV, 127-128.

28. En Olaechea Albistur, R., "Información y acción política: El conde de Aranda", nº 7 , Investigaciones históricas, Valladolid, 1987, p. 90.

29. Se encuentran numerosas referencias al asunto en Olaechea Albistur, R., "Información..., pp. 81-130. 
Es probable que por este motivo Grimaldi dispusiese el traslado en 1774 de Fernando Magallón, anterior secretario de la embajada, a Paris con el pretexto de negociar desavenencias en las fronteras pirenaicas. Sobre su presencia circulaban rumores de que realmente se encontraba en Francia para espiar a Aranda y establecer un canal paralelo de comunicación entre Grimaldi y D’Aiguillon, sucesor de Choiseul $^{30}$. A cambio Aranda conseguiría ganar aparentemente a su causa al oficial Bernardo del Campo como su informador desde la secretaría de Estado, aunque en la práctica jugaría a dos bandas y no le proporcionaría noticias significativas que realmente pudiesen perjudicar a Grimaldi.

Este, de hecho, no desaprovecharía cualquier ocasión que se le presentase para tratar de desacreditar a Aranda, sin mostrar rubor alguno en traslucir una cierta satisfacción ante sus dificultades en Versalles, como pondría de manifiesto a Floridablanca en mayo de 1775 con la siguiente afirmación, por otra parte representativa de su forma de actuar en política ${ }^{31}$ :

el Ministerio de Francia no va muy acorde con nuestro Aranda. El conde no se ha hecho amar allá, y así, sus representaciones no serán muy atendidas. Eso que digo de Aranda quede entre los dos, y aún así pido a VSI. que una vez leída queme esta carta.

El mismo Grimaldi contribuiría a esta situación de forma sutil, unas veces ocultando informaciones a Aranda y otras no respaldándole ante sus interlocutores, para desesperación del conde, cuyo menosprecio por el secretario de Estado iría en aumento. Por su parte, Aranda intentaría aprovechar la menor oportunidad para socavar la posición de Grimaldi, pero sus esfuerzos serían infructuosos y tendría que aguardar hasta el año 1776, cuando se organizó la malograda expedición a Argel.

De este modo, en el verano de 1773 las tornas habían cambiado y Grimaldi parecía haber salido triunfante, con Aranda en Francia y su puesto en el Consejo de Castilla cubierto por un calmoso Ventura Figueroa. Pero la prolongada estancia del conde en el país vecino no implicó que dejase de lado ni la política española ni su fijación por Grimaldi. De hecho aún desde la distancia le sometería a una estrecha vigilancia, anotaría cuidadosamente sus errores políticos y se los reprocharía sin tapujos al objeto de debilitar su posición y desbancarlo. Tal sucedería durante la breve guerra con Marruecos a principios de 1775 o en el transcurso del conflicto con Portugal por la Banda Norte del Río de la Plata, en el que según la opinión de Aranda Grimaldi había actuado de una forma tan desacertada como "antiespañola". El conde no consiguió su objetivo ni en uno ni en otro caso, que de cualquier modo no eran sino anticipos de la feroz campaña

30. Olaechea Albistur, R., "Información..., p. 88.

31. Carta de Grimaldi a Floridablanca de 7 de mayo de 1775, Archivo de la Embajada Española en Roma, Legajo, 623, cit. Olaechea Albistur, R., “Información..., pp. 88. 
emprendida contra el secretario de Estado tras el fracaso de Argel en julio de 1775, en la que Aranda tendría una destacada participación ${ }^{32}$.

\section{La caida de Grimaldi}

A pesar del alejamiento de su líder natural, el "partido aragonés" continuaría actuando en la corte agrupado en torno al príncipe de Asturias para ganar su favor en la pugna contra los "golillas", que seguía con la misma intensidad. El príncipe formaría su propia lista de agravios contra el rey, entre los que destacaba el hecho de que no le hubiese confiado asunto alguno de importancia hasta la fecha. Carlos III era especialmente consciente de la debilidad de carácter de su heredero y de su falta de criterio para distinguir a los intrigantes y aduladores de los verdaderos colaboradores. A estas carencias contribuiría María Luisa de Parma, con quien se había desposado en $1765^{33}$.

De este modo, la oposición encontró una actitud receptiva por parte de los príncipes. Sin embargo, el monarca desaprobaba abiertamente, con las consecuencias que se verán más adelante, que en sus cuartos, sobre todo en el de María Luisa, se concentrase una camarilla de aristócratas favorables al partido "aragonés", opuesta a la política internacional de los Pactos de Familia y a la participación en el gobierno de "golillas" y extranjeros. Este grupo, si bien solía actuar con discreción, en ocasiones extremaba sus posturas sin la menor delicadeza, como se pondría de manifiesto con ocasión del fracaso de la expedición a $\operatorname{Argel}^{34}$.

El desencadenante de la funesta empresa militar sería el hecho de que la guerra con Marruecos hubiese finalizado contra todo pronóstico en menos de tres meses, dejando en el aire la operación de castigo contra las costas marroquíes que Grimaldi, con la aquiescencia del rey, había proyectado, y que a mediados de marzo de 1775 parecía desaconsejar la inminente paz. Aranda era de la opinión contraria, habida cuenta de que ya habían comenzado los preparativos y ejecutado los gastos necesarios y de que consideraba la iniciativa como una buena oportunidad para impulsar la construcción naval sin despertar sospechas en Inglaterra ${ }^{35}$.

Finalmente se optó por continuar con los preparativos de la expedición, pero dirigiéndola contra otro objetivo: la regencia de $\operatorname{Argel}^{36}$. Grimaldi fue culpado en

32. Olaechea Albistur, R., "Información..., p. 94.

33. Vid. Egido, T., Carlos IV, Barcelona, 2001.

34. Fernández, R., Carlos III..., pp. 161-162.

35. Aranda expresaba esta idea a Grimaldi en sus cartas de 10 y 24 de abril. En esta ultima decía "que si el proyecto de la expedición dispuesta estaba bien digerido seria lastima malograr los gastos". (AHN, Estado, Legajo 4351). Cit. Rodríguez Casado, V., Política marroquí de Carlos III, Madrid, 1946, p. 235.

36. Vid. Palacio Atard, V., "Paz con Marruecos y guerra con Argel. Los Turcos", en España y el mar, pp. 387-402; Martínez Torres, J. A., "Corso turco-berberisco y redenciones de cauti- 
su momento, tras el fracaso de la empresa, de ser el responsable único de este cambio, obviando interesadamente que tanto el confesor real, Eleta, como el obispo de Segorbe, fray Alonso Cano, tuvieron una contribución determinante al respecto. De hecho, los desencaminados argumentos de Cano fueron insistentemente reiterados en los círculos de la corte y transmitidos por Eleta al mismo rey. Por su parte, el dey de Argel continuaba dando motivos para una respuesta militar con los constantes apresamientos de buques españoles en el Mediterráneo. En este contexto Grimaldi, contando con el apoyo de otros secretarios como Ricla, partidario de Aranda, se decantaría por proponer al rey dirigir la expedición contra Argel. Carlos III, que ya en el reino de Nápoles había sufrido las consecuencias de la piratería berberisca y deseaba ponerle fin, no lo pensaría más y aprobaría el plan.

La exoneración parcial de la responsabilidad de Grimaldi y la atribución de un papel determinante a Cano y Eleta fueron defendidas por A. Ferrer del Río, el cual afirmaría que "el pensamiento de esta expedición lo concibió el padre misionero Cano, obispo de Segorbe, y antes redentor de Trinitarios; lo aceleró Fr. Joaquín Eleta, confesor del rey, estimándolo cosa Ilana, y lo resolvió Carlos III como empresa ajustada a las tradiciones españolas, a su fe católica y al deseo de aumentar la gloria de la nación" y por V. Rodríguez Casado, al señalar que Alonso Cano y Joaquín de Eleta "interpretaban el sentimiento del pueblo como muy favorable a aquella empresa, de tan señalado carácter de cruzada". En una fecha tan próxima a los acontecimientos como el 15 de agosto de 1775 el marqués de Almodóvar escribiría a Mayans en relación a la expedición señalando "al obispo de Segorbe y al arzobispo de Thebas" como culpables del fracaso ${ }^{37}$.

Grimaldi confiaba en conseguir dos objetivos: poner fin a la amenaza contra la navegación que representaban los piratas argelinos y demostrar la fuerza de las armas españolas al sultán de Marruecos, disuadiéndole de forma definitiva de nuevos ataques contra los presidios. Además, las declaraciones de Sidi Mohammed en el sentido de que se desquitaría de los argelinos por el incumplimiento de su promesa de hostigar Orán para distraer a los españoles durante el asedio de Melilla hacía albergar a Grimaldi la esperanza de que la expedición por mar se viese facilitada por un ataque marroquí a la regencia por tierra ${ }^{38}$.

vos en el Mediterráneo occidental (s. XVI-XVII)", en KAISER, W. (ed.): Le commerce de captifs. Les intermédiaires dans l'échange et le rachat des prisionniers en Méditerranée, XVe.-XVIIIe. siècle, Roma, 2008, pp. 64-80.

37. Ferrer del Río, A., Historia..., p. 765; Rodríguez Casado, V., Política marroquí..., p. 236; Escribano Páez, J.M. y Castillo Larriba, R., Argel Delenda Est. El "Nuevo Aspecto de la Topografía de la Ciudad y Regencia de Argel" de Fray Alonso Cano y Nieto, Alcalá, 2010, pp. 20-21.

38. Las esperanzas de Grimaldi en el apoyo marroquí serían muy criticadas por Aranda en su carta de 20 de agosto de 1775, tras el fracaso de la expedición española (AHN, Estado, Legajo 4351). 
La única duda era la persona indicada para conducir la expedición. Había dos candidatos que sobresalían sobre el resto: Cevallos y O’Reilly. El monarca llamó primero a consulta a Cevallos, que presentó un proyecto cuyas necesidades eran difíciles de satisfacer, sobre todo por los 40.000 soldados y marinos que afirmaba necesitar para la expedición. O’Reilly, llamado días más tarde, se comprometió en cambio a conquistar Argel con solo la mitad de los efectivos pedidos por Cevallos. El militar irlandés, bien visto por Grimaldi, prometía algo que era difícil cumplir, pero que halagaba los oídos de sus interlocutores, de modo que finalmente fue el escogido ${ }^{39}$.

En el mes de julio de 1775, Tras el fiasco de la expedición a Argel, el desembarco en Alicante de los maltrechos supervivientes acarreó en toda España una tempestad de críticas, violentas y amargas unas, irónicas otras, que amenazarían con derribar a O'Reilly y de paso a su patrocinador, Grimaldi. La imagen de España en el extranjero, revalorizada tras la guerra de Marruecos, quedó dañada hasta el punto de que el mismo duque de Gloucester se permitió expresiones despectivas sobre el acontecimiento, lo que no era sino una muestra de los comentarios que corrían por las cortes europeas.

De inmediato se ordenó que se elaborase una Relación, que se hizo pública incluyendo en ella el informe de O'Reilly en el que se achacaba el fracaso "al sobrado ardor con que se adelantó la tropa e hizo sus fuegos" Curiosamente el comandante de la flota, Castejón, a pesar de encontrarse durante todo el combate alejado de la costa a bordo del navío insignia, respaldaba esta teoría, afirmando en sus informes que "el desgraciado incidente de haber querido nuestra Ala izquierda, llena de valor, selo y ardimiento, adelantarse demasiado, sin orden del General, por unos caminos quebrados y desconocidos para nuestras gentes, ha causado el malogro de esta bien convinada empresa".

Poco después se publicaba otra Relación, cuyo autor era esta vez el propio jefe de la expedición ${ }^{40}$. Aun así Ricla encontró confusas algunas de las noticias que O'Reilly refería, por lo que le escribió solicitando nuevos informes ${ }^{41}$. Como respuesta el general irlandés aseguró haber cumplido con su deber y señalando de nuevo como motivo del fracaso "el sobrado ardor de la tropa al principio", si

39. Sobre la figura del militar irlandés Vid. Torres Ramírez, B., O’Reilly en Cuba, Anuario de estudios americanos, tomo 24, 1967; del mismo autor, O’Reilly en las Indias, Sevilla, 1969; Caro Costas, A. (ed.), "Memoria de D. Alexandro O"Reylly sobre la isla de Puerto Rico", en Antología de Lecturas de Historia de Puerto Rico (Siglos XV-XVIII), San Juan, 1980; Terrón Ponce, J.L., "La década O’Reilly", en Ejército y Política en la España de Carlos III, Madrid, 1997, pp. 36 a 46; Parcero Torre, C., "El primer plan para la defensa de Cuba", en Revista Mexicana del Caribe, $\mathrm{n}^{\circ}$ 15, Chetumal, 2003, pp. 137-158.

40. AGS, Guerra Moderna, Legajo 2004, Relación puntual de lo acaecido en la expedición hecha contra Argel en el año de 1775 rubricada con la firma autógrafa del Conde de O'Reilly.

41. AGS, Guerra Moderna, Legajo 2008, minuta de la solicitud del Conde de Ricla a O'Reilly (citado en Dos expediciones españolas contra Argel, 1541 y 1775, Publicaciones del Estado Mayor Central, Servicio Histórico Militar, Madrid, 1946, p. 134). 
bien esta vez añadía que "lo reparó en cuanto fue posible su constancia", argumentos que Grimaldi haría suyos para intentar defenderse del aluvión de críticas que a partir de ese momento surgirían en su contra ${ }^{42}$.

A partir del momento mismo en que se tuvo conocimiento del desenlace del frustrado desembarco comenzaría una intensa e incesante campaña para desacreditar tanto O'Reilly como a Grimaldi, que solo tenía parangón en los sucesos de 1766 y que adoptaría múltiples y variadas formas ${ }^{43}$. Destacaría de entre ellas la sátira que se conserva en la Biblioteca Nacional "Tragedia nueva sobre Alexandro (O’Reilly) en África. Su autor Don Gerónimo Grimaldi. Con licencia del Rey N. Sr. Año de 1775. Se hallará en las casas de Iriarte, Campo y Compañía. Impresa a costa de la nación española y de la sangre de la nobleza"144.

Al contrario de lo sucedido en los motines de 1766, en esta ocasión no llegaron a producirse altercados ni se vio amenazado el orden público, quizá por el hecho de que las criticas se propagaron con tanta profusión por las calles y por los principales círculos de Madrid y Barcelona en forma de pasquines, anónimos, letrillas, etc., que por esta vía se dio salida al desahogo de una parte significativa del descontento. Ello no fue obstáculo para que llegase a difundirse la noticia de un proyecto para quemar la casa de Grimaldi, que supuestamente debía haberse llevado a cabo el 16 de agosto de 1776. No está claro que este atentando llegase a formar parte de un autentico plan, aunque sí hay testimonios de Ferrer del Rio y dos cartas, una de 13 de agosto de 1775 y otra sin fecha, de Pedro José Messía a Grimaldi dándole cuenta de que había logrado disuadir a cuatro individuos de "tan enorme pecado"

La situación en aquel momento era confusa, por lo que se adoptaron algunas medidas preventivas ante la eventualidad de que se produjesen desórdenes como los que llevaron a la caída de Esquilache. Así, desde el 20 de julio de 1775 Grimaldi, alarmado, no se cansaría de urgir al presidente del Consejo de Castilla, Ventura Figueroa, para que ordenase actuaciones policiales con el objeto de dar con los autores y distribuidores de la gran cantidad de papeles que circulaban por Madrid. Grimaldi diría al respecto el 25 de julio de 1775 que estos eran "un mal que influye en todas las operaciones del gobierno"446. Todavía días después de su dimisión afirmaría que la investigación debía acelerarse "no por mí, que me voy, pero por la tranquilidad del rey, buen gobierno del Estado y, se puede añadir, por la felicidad de la monarquía, es muy importante que se descubran

42. AGS, Guerra Moderna, Legajo 2008, carta de O'Reilly a Ricla de fecha 30 de julio de 1775.

43. Cit. Egido López, T., "La oposición y el poder..., pp. 430-431.

44. Aparece con el número 2436 en Aguilar Piñal, R., Bibliografía de autores españoles del siglo XVIII, vol. 4, Madrid, 1986. p. 428.

45. Ferrer del Rio, A., Historia..., pp. 148-149. Egido López, T., "La oposición y el poder...,

46. Cartas de Grimaldi a Ventura Figueroa de 25 de julio, 14 y 30 de agosto de 1775, en AHN, Estado, Legajo 6437. Cit. Egido López, T., "La oposición y el poder..., p. 426. 
los cómplices de la trama"147. Las referencias a este asunto en la correspondencia entre ambos eran tan frecuentes que en el Consejo de Estado llegó a abrirse un expediente titulado "Correspondencia secreta con el Sr. Grimaldi sobre averiguación de los autores de diferentes pasquines".

La publicación en la Gaceta de Madrid de informaciones poco ajustadas a la realidad solo sirvió para encrespar aun más los ánimos de la opinión pública y de los militares, ofendidos porque en ellas se hablaba de falta de disciplina de los cuerpos que intervinieron en las operaciones, lo que llevó a que protestasen con energía ante el teniente general y el gobierno. Como remate, los rumores acerca de la posible responsabilidad del fracaso en la actitud del marqués de la Romana, muerto en la acción, movieron a su hermano, don Ventura Caro, a reivindicar su honor y a presentar una sonada reclamación a Ricla en el mes de septiembre. Lo más grave fue que en el transcurso de las investigaciones de Caro se supo que los rumores se basaban en una filtración de Grimaldi, seguramente intencionada, a los círculos de la corte de una carta confidencial que Ricardos le había dirigido. El rey zanjaría el asunto en el mes de noviembre de 1775 mediante una comunicación en respuesta a la representación de Ventura Caro en la que declaraba fuera de lugar cualquier cuestionamiento de la conducta del marqués de la Romana.

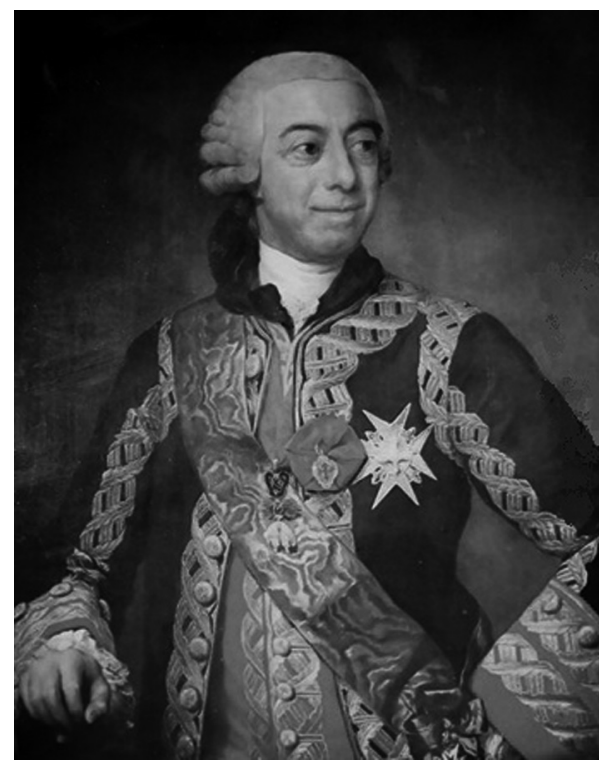

Figura 5. Fernando de Silva, Duque de Huescar y $12^{\circ}$ Duque de Alba, por Rafael Mengs, Palacio de Liria. Fuente: http://upload.wikimedia.org/wikipedia/ commons/8/8f/12th_Duke_of_Alba_by_ Mengs.jpg.

Tampoco Aranda ocultó su indignación al enterarse de que se había dado orden de que la documentación relativa a la expedición se archivase en la se-

47. Carta de Grimaldi a Ventura Figueroa de 14 de noviembre de 1776, en AHN, Estado, Legajo 6437. 
cretaria de Guerra como ejemplo para posteriores operaciones. El conde elaboró un informe muy crítico y pormenorizado que remitió de inmediato a España. Resentido también por no haber podido intervenir en la campaña, Aranda atribuiría a Grimaldi toda la responsabilidad y no vacilaría en hacerle llegar directamente sus reproches, como en las cartas cifradas que le enviaría en agosto, noviembre y diciembre de $1775^{48}$. La reacción de Grimaldi, por otra parte lógica, sería la de contestarle que en lo sucesivo se abstendría de contestar sus cartas confidenciales, pues "el orden y la regla prescriben que sólo en cartas y despachos de oficio se traten los negocios, de modo que me conformaré exactamente a ella"49.

Las críticas en la calle no se limitaban a Grimaldi y a O’Reilly, sino que pronto se hicieron extensivas a otros italianos como el auditor Vicenti, el consejero de Hacienda Pico de la Mirandola o el ayuda de cámara Pini, ya zaheridos por la sátira clandestina durante el motín de Esquilache. Tampoco escaparon a los ataques los colaboradores de Grimaldi en la secretaría de Estado como Bernardo del Campo y otros personajes, entre ellos Campomanes y el confesor real Eleta. Este hecho y la circunstancia de que los "aragoneses" presentes en el gobierno, como Ricla o Roda, o sus aliados, como Bernardo de Iriarte, saliesen indemnes de la oleada de pasquines, folletos e invectivas que inundaron Madrid y Barcelona, no deja albergar duda alguna sobre el papel del "partido aragonés" en la organización de esta campaña.

Tampoco tenía dudas al respecto Grimaldi, como indicaría su afirmación a Ventura Figueroa de que tratándose de "escritos infames que se leen en las conversaciones, no se necesita mucho para ir al origen de los distribuidores y acaso autores $^{\prime \prime 50}$. El seguimiento de la correspondencia de Jerónimo Grimaldi en este periodo pone de manifiesto lo justificado de su preocupación por descubrir a los instigadores. Y es que el hecho de que las pesquisas oficiales a tal fin no diesen resultados dignos de reseñar no ocultaba que los responsables de su redacción recibían aliento e inspiración de la aristocracia contraria a la presencia de extranjeros en la alta administración borbónica, hasta el punto de que Grimaldi diría a Ventura Figueroa que "se ve claro que quieren mandar (...) que todo sale de una misma fragua (...) que los motores e impelentes son superiores" ${ }^{\prime \prime 51}$.

El estado de opinión descrito tenía que influir necesariamente en el ánimo del rey, que a pesar de ello intentó proteger de las murmuraciones y calumnias tanto a Grimaldi como a O’Reilly. El monarca se vio obligado a exteriorizar su desagra-

48. Cartas de Aranda a Grimaldi de 20 de agosto y de 17 de noviembre de 1775, en AHN, Estado, Legajo 4351.

49. Carta de Grimaldi a Aranda de 8 de diciembre de 1775, AHN, Estado, Legajo 2831/1, cit. Olaechea, R., "Información..., p. 95.

50. Carta de Grimaldi a Ventura Figueroa de 26 de noviembre de 1776, en AHN, Estado, Legajo 6437. Cit. Egido López, T., "La oposición y el poder..., p. 444.

51. Cartas de Grimaldi a Ventura Figueroa del 11 al 24 de septiembre de 1776 (AHN, Estado, Legajo 6437, cit. Egido López, T., “La oposición y el poder..., p. 445). 
do hacia este último, alejándole de la corte con el pretexto de encomendarle una nueva misión, la visita de las islas Chafarinas.

En cuanto a Grimaldi, continuó ejerciendo su cargo, pero en circunstancias bien difíciles. La campaña de desprestigio a que se vio sometido no terminó con el nuevo destino a Andalucia de O’Reilly, conocido ya como "el general del desastre", sino que continuó auspiciada por los políticos y aristócratas partidarios de Aranda, llegando a su momento cumbre con la intervención del príncipe de Asturias que, influenciable y débil de carácter, se dejaría arrastrar por la corriente.

Jerónimo Grimaldi no tardó en ser consciente de ello, y por ese motivo intentó reconducir la situación convenciendo al rey para que permitiera al heredero asistir a las reuniones nocturnas de trabajo, al menos cuando se discutieran temas de política exterior, con la esperanza de reforzar su credibilidad ante el príncipe y de privar de un arma a sus contrarios. De este modo Grimaldi pretendía que no pudiesen "los malignos decir que se engaña al rey o que se oculta la verdad", ni utilizar como pretexto al heredero "porque la entrada del Príncipe en el despacho les haya cortado el pretexto de decir que S.A. desaprobaba esto o lo otro" ${ }^{\prime 52}$.

Pero el intento de Grimaldi sería en vano puesto que no iba ser fácil frenar al heredero, que expuso sus ideas -o las del partido "aragonés" y Aranda- en una serie de intervenciones en las reuniones del gabinete, siendo solo refrenado por el propio monarca. En estas circunstancias fue cuando Carlos III se dirigió privadamente a su hijo mediante una larga epístola para hacerle llegar un amargo reproche, advirtiéndole de paso de que la asociación con la oposición contra los ministros del rey acabaría volviéndose contra él ${ }^{53}$ :

Corre por el Reyno que hay dos partidos en la Corte; el daño que esto puede causar no es ponderable, y es más contra ti que contra mí, pues lo has de heredar, y si creen que esto sucede ahora entre Padre e hijo, no faltaran gentes que, con los mismos fines, sugerirían a las tuyas de hacer lo mismo contigo.

Este consejo no pareció impresionar al príncipe, y el partido "aragonés", manejado a distancia por Aranda, dominado por la aristocracia y con la protección del heredero, continuó actuando como una eficaz oposición caracterizada ante todo por su carácter destructivo. Su voz en ausencia de Aranda la llevaba Ramon Pignatelli, canónigo de Zaragoza y hermano del conde de Fuentes, gracias al predicamento de uno de sus sobrinos cerca del príncipe de Asturias. Pignatelli pretendía por otra parte suceder a Grimaldi al frente de su ministerio.

52. Cartas de Grimaldi a Ventura Figueroa de 5 de septiembre y 26 de noviembre de 1775, en AHN, Estado, Legajo 6437. Cit. Egido López, T., "La oposición y el poder..., p. 444.

53. Carlos III al príncipe de Asturias, en Dánvila y Collado, M. Reinado de Carlos III, Madrid, 1891-1894, El reinado de Carlos III, IV, pp. 275-277. 
A pesar del apoyo real, Grimaldi quedaba en una situación expuesta en la que iba a serle difícil sostenerse mucho tiempo. Al marqués no se le ocultaba que estaba aislado políticamente ni que su intento de ganar el favor del heredero había sido infructuoso ${ }^{54}$. Además, buena parte del ministerio le era adversa: Roda estaba bien relacionado con Aranda. Ricla y Múzquiz pertenecían al partido "aragonés" y la muerte de Arriaga en febrero de 1776 suponía otro golpe para la continuidad de Grimaldi en la secretaría de Estado, puesto que los secretarios que le sucedieron, José de Gálvez, incondicional de Múzquiz, en Indias y Pedro González de Castejón, enemigo de O’Reilly, en Marina representaban un notable refuerzo en el gabinete de la oposición.

Por otra parte, tampoco cabía esperar en esta ocasión el apoyo de Francia, el principal aliado de España, para apuntalar al secretario de Estado, como había sucedido durante la etapa de Choiseul. En esta ocasión se juntaban la reciente sucesión en el trono francés y la escasa relación entre Maurepas y Grimaldi con el debilitamiento de la alianza franco-española tras la decepción causada por la actitud gala en la crisis de Malvinas. Por si esto era poco, se sumaba el hecho de que el principal enemigo de Grimaldi, Aranda, en su condición de embajador ante la corte de Luis XVI, no desaprovechaba ocasión de pronunciarse en su contra y de atribuirle la responsabilidad en el fracaso de Argel.

El desenlace se pospondría algunos meses por la distracción que supuso para la opinión pública la promulgación de la pragmática sanción sobe matrimonios desiguales de 23 de marzo de 1776 y su aplicación en el caso del matrimonio morganático que el infante don Luis Antonio, hermano del monarca, había contraído el 27 de junio con María Teresa de Vallabriga. La pragmática, cuya paternidad se atribuía a Grimaldi, recordaba la costumbre y obligación de los Infantes y Grandes de España de solicitar real licencia para sus casamientos y los de sus descendientes, bajo pena a cuantos omitieran este requisito de perder los títulos, honores y bienes demandados de la Corona. Como es conocido, a resultas de la aplicación de la pragmática el infante quedaría finalmente excluido de la línea sucesoria y se vería desterrado de la corte. La intervención de Grimaldi para dar cumplimiento a la voluntad del monarca en la cuestión del matrimonio de don Luis no se habría limitado a la redacción de la pragmática, sino que se extendió a la misma ceremonia, puesto que al parecer fue el propio Grimaldi quien terminó de convencer a la remisa novia para que contrajese matrimonio ${ }^{55}$.

Pero en cuanto el asunto de la boda pasó de nuevo arreciaron las críticas a Grimaldi y el cuestionamiento de su continuidad en el puesto de secretario de Estado. El desgaste era ya muy intenso y parecía que finalmente Grimaldi aceptaba lo inevitable al afirmar a un amigo en el palco de la ópera en Aranjuez "ha llega-

54. En su carta a Ventura Figueroa de 14 de noviembre de 1776 (AHN, Estado, Legajo 6437) le decía que se enfrentaba a un grave asunto de estado "pero vienen indiciadas tales personas de quien de ningún modo convenga hablar".

55. Olaechea, R., "Información..., p. 122. 
do la hora de que me vaya". En el ambiente cultural se produciría precisamente el incidente definitivo que precipitó su renuncia. En concreto fue la controversia surgida a colación del nombramiento por Grimaldi de Antonio Ponz para sustituir a Ignacio Hermosilla en la Academia de San Fernando, de la que el secretario de Estado era protector. Las adustas réplicas y contrarréplicas que se sucedieron no hicieron sino atizar aún más las murmuraciones por Madrid contra Grimaldi.

Sin prácticamente capacidad de decisión por falta de apoyos, con el resto de los ministros en su contra y desengañado por las críticas de algunos de los que consideraba sus partidarios, Grimaldi planteó el asunto de su dimisión al monarca, que la acogió de mala gana, pero que por la insistencia del marqués terminó admitiéndola. Carlos III aconsejó a Grimaldi que presentara la instancia a despacho por vía del secretario de Gracia y Justicia, Roda, lo que llevó a cabo el 7 de noviembre de $1776^{56}$.

Dos días después el monarca admitía la renuncia, fundada en la falta de salud de Grimaldi, haciéndole constar su sentimiento así como la satisfacción por los servicios prestados, de lo que daba prueba nombrándole embajador en Roma en sustitución de Floridablanca, que para sorpresa general, era escogido como su sucesor al frente de la secretaría de Estado ${ }^{57}$. De este modo patrocinador y patrocinado intercambiarían sus puestos.

En los primeros días que siguieron a la dimisión el rey, que perdía un amigo y colaborador, se mostró desabrido y melancólico, al tiempo que Grimaldi no ocultaba su regocijo y se mostraba complaciente con los muchos que le hacían llegar su enhorabuena. Sin embargo, poco tiempo después se tornarían los papeles y el secretario cesante mudaría su optimismo por la tristeza.

Es bastante probable que la tristeza de Grimaldi fuese únicamente melancolía por el final de su carrera política, pero lo que parece seguro es que en su alegría, más o menos disimulada, influía de manera determinante el hecho de que justo en el momento en que parecía manifiesta su derrota realmente había conseguido dos victorias decisivas sobre sus enemigos.

La primera de ellas tendría un toque personal. En diciembre de 1775 Pablo de Olavide, rico propietario e ilustrado nacido en Lima y protegido de Aranda, su gran valedor y amigo, había regresado a Madrid desde sus poblaciones de Sierra Morena con el objeto de defenderse de las acusaciones de que había sido objeto ante la Inquisición y ante el mismo confesor real, Eleta. Con un arranque de audacia, el 12 de febrero de 1776 se presentó ante el inquisidor Beltrán, con ánimo de "sincerarse", después de haberlo hecho con Roda. Era un intento desesperado

56. AHN, Estado, Legajo 3421, Expediente Personal de Jerónimo Grimaldi, carta de dimisión fechada el 7 de noviembre de 1776.

57. El nombramiento de Grimaldi como embajador en Roma fue comunicado por Carlos III a Tanucci en su carta de 12 de noviembre de 1776. La respuesta a la dimisión y el nombramiento de embajador en Roma se encuentran en AHN, Estado, Legajo 3421, Expediente 5 Servicio Exterior, 4 c (Secretaría de Estado). 
de Olavide de salir airoso de una situación provocada en por la denuncia de un fraile alemán, que la Inquisición había hecho suya a causa de la convivencia en concubinato del peruano. Jerónimo Grimaldi, uno de sus "amigos", le había alertado de las acusaciones y de la instrucción del proceso.

De nada serviría la confesión de Olavide, puesto que tras las declaraciones de los testigos, el 14 de septiembre de 1776 se decretaba "que este sujeto sea preso en la cárceles secretas deste Santo Oficio, con secuestro de todos sus bienes, libros y papeles, y se siga su causa hasta definitiva". El 29 de octubre daba su aquiescencia el rey, requisito indispensable para hacer efectiva la condena, y el 14 de noviembre de 1776 ingresaba Olavide en prisión incomunicada, donde permanecería dos años. La sentencia, propia de siglos anteriores, desmoralizó sobre todo a Aranda, pero también a Azara y a otros "aragoneses" próximos a Olavide y suscitó el escándalo en los salones de las ilustradas cortes europeas ante la inhibición del monarca y de todo el mecanismo de la administración civil en favor de un instrumento, la Inquisición, del que hacía décadas que no se había hecho uso para castigar a un personaje de la relevancia de Olavide ${ }^{58}$. La conclusión general era la de que se había tratado de un "arranque de autoridad real" como toque de atención y llamada al orden a ciertas personas, probablemente en particular a Aranda, que tuvo el efecto deseado puesto que ni de dentro ni desde fuera se exteriorizó protesta alguna.

Las últimas investigaciones señalan que tanto los ministros de Carlos III, encabezados por Grimaldi, como el propio rey y su confesor Eleta habían elegido como víctima ejemplar a Olavide para vengarse de su protector Aranda, que además de su campaña de acoso y derribo del gobierno de "golillas" (plebeyos, italianos y "abogaduchos", todos "cagatintas" según sus propios términos), no había dudado en involucrar en sus planes a través del partido "aragonés" a los príncipes de Asturias. El efecto negativo sobre Carlos III de tal situación ya es conocido, llevándole su irritación a prestar oídos a la idea de sus ministros -Múzquiz, Roda y sobre todo Grimaldi- de buscar un chivo expiatorio que mostrara a los conspiradores que al rey no le temblaría el brazo, puesto que no parecía posible castigar al conde de Aranda, dos veces grande de España. Mejor aún si, además, el rey se valía de la Inquisición. Se desquitaba así Grimaldi de Aranda en la figura de su intimo amigo Olavide, a quien con casi total seguridad despreciaba en su fuero interno, aunque exteriorizase lo contrario, lo que no es sino una muestra más de su personalidad ${ }^{59}$.

La segunda victoria de Grimaldi tuvo mayor trascendencia. Los últimos meses de 1776 eran cruciales, puesto que en ellos se decidiría definitivamente la lucha

58. Vid. Gómez Urdañez, J.L., "Pablo de Olavide y Jáuregui. Un católico ilustrado", en Brocar, no 28, Logroño, 2004, pp. 7-30.

59. Gómez Urdañez, J.L., "El padre es el rey: Carlos III y Carlos IV ante las intrigas del cuarto del príncipe", Coloquio internacional Le pere comme figure d'autorite dans le monde hispanique Saint-Etienne, 2012. 
entre el "partido aragonés" y los ministros, entre aristocracia y burocracia, entre "colegiales" y "golillas", en la que todo el espectro de la opinión y los intereses políticos intentarían conseguir el favor del rey. Aranda maniobraba desde Francia con el objeto de que la rumoreada crisis ministerial llevase a la secretaría de Estado a alguno de sus incondicionales del "partido aragonés", aunque personalmente se consideraba la persona propicia para ocupar el puesto del defenestrado Grimaldi. En esta línea cometería una grave equivocación al remitir en el mes de octubre a Osma, cuya correspondencia estaba intervenida, un pliego dirigido al rey en el que se postulaba a sí mismo "para el mejor servicio del Príncipe y de la Nación". Por una u otra razón Osma, que probablemente dio a conocer el pliego a los enemigos de Aranda, no acusaría recibo del mismo hasta mediados de 1778, cuando ya hacía más de año y medio que Floridablanca dirigía la secretaría de Estado.

Aranda no había sido consciente de que a finales de 1776 Grimaldi contaba todavía con influencia y con el apoyo de su propia "covachuela" y, sobre todo, con el favor del rey, reacio a que el conde se saliese con la suya. Grimaldi tenía otros designios, a través del oficial Bernardo del Campo, aparentemente afín a Aranda, pero en la práctica con dobles lealtades, movilizaría a la oposición en favor de Floridablanca, al tiempo que personalmente sugería su candidatura al rey. Por esas mismas fechas comentaba Grimaldi a Ventura Figueroa que "vamos a poner a uno de los nuestros". Carlos III aceptó esa idea, y Floridablanca, hombre de los "golillas" y los reformistas, pasó a ocupar el cargo de secretario de Estado en febrero de 1777. Con el nombramiento de Floridablanca se había cerrado el camino a cualquier posible alternativa, y el partido "aragonés" no conseguía salir beneficiado de la dimisión de Grimaldi, que en gran medida había contribuido a provocar.

En cuanto a Aranda, seguiría confinado en París. Sin embargo, desde su embajada no tardaría en felicitar a Floridablanca, dado que al menos era español y no estaría condicionado "por el poco apego de que es susceptible el que no puede pronunciar bien cuerno, cebolla y ajo ${ }^{\prime \prime 60}$. Esta felicitación no podía ocultar la desilusión que causó en la aristocracia tradicional verse de nuevo excluida del poder, que se otorgaba en esta ocasión a una persona de extracción social humilde. Su frustración se pone de manifiesto en la composición satírica, denominada "Junta Anual de la sociedad antihispana celebrada el día de Inocentes de 1776", en la que se ponía en boca de Grimaldi ${ }^{61}$ :

Pero no les salió como pensaban, porque les he dado el gran petardo de deshacer sus máquinas y enredos poniendo en mi lugar a un hombre bajo,

60. Ferrer del Rio, A., Historia del Reinado..., p. 178.

61. Cit. Egido López, T., “La oposición y el poder..., p. 449. 
de corazón torcido, y tan perverso, que aparenta candor y encubre rayos.

Con este sucesor tapo la boca

a los que están conmigo disgustados, y por librarse de tan fiera bestia se alegrarán de que yo siga mandando

Precisamente una de las primeras medidas de Floridablanca sería proponer que se otorgase a su predecesor la grandeza de España y el titulo de duque de Grimaldi. No debe extrañar por tanto que Jerónimo Grimaldi no pudiese evitar dejar traslucir su alegría antes de emprender su viaje hacia Roma. Seguramente imaginaba el semblante de Aranda, que dolido y escarmentado solo podía dar rienda suelta a su enfado clamando por la salida de Grimaldi de España en el menor plazo posible y diciendo " $i$ Cuando querrá Dios que este hombre (Grimaldi) pase los Pirineos (con destino a Roma) para que no avergüence más a la pobre España?"62.

62. Carta de Aranda a Oquendo de 4 de febrero de 1777, AHN, Estado, Legajo 2825. 